doi: $10.12957 /$ childphilo.2021.55770

\title{
authenticity as an inarticulate ideal in the contemporary discourse of good childhoods
}

\author{
luiz do valle miranda ${ }^{1}$ \\ charles university in prague, prague, czechia \\ orcid id: https://orcid.org/0000-0003-1838-5693
}

\begin{abstract}
This paper consists of an initial investigation about the meaning of a good childhood following the ethical ideal of authenticity. In this introduction to a philosophy of childhood and authenticity, the central theme is to investigate how the authenticity ideal is already presupposed in the contemporary discourse on what constitutes a good childhood. In the emerging field of philosophy of childhood, the capacities of children for agency, autonomy, and committing and the fundamental role of parents in guaranteeing possibilities to exercise them are being increasingly highlighted, together with a discourse that there are some intrinsic goods of childhood. These developments parallel contemporary reconstructions of authenticity as an ethical ideal. Current debates emphasize the importance of finding, creating, and constructing their originality and how to realize it. At the same time, this search must recognize demands emanating from something more than human desires: from one's culture and community. The parallel dynamics between these two discourses - children-parent and individual-society - point to a direction that applying the concept of authenticity to the construction of novel interpretations and practices of a good childhood can bring fruitful results. After examining such parallels, some of these practices that emerge from the analysis of good childhoods as authentic childhood are pointed out, such as the importance of cultivating children's moments of caring and committing and developing personal projects. The paper concludes by exploring some limitations of the applied methodology and strengthening future research on this topic.
\end{abstract}

keywords: childhood; authenticity; moral-psychology; personal projects.

\section{a autenticidade como ideal inarticulado no discurso contemporâneo sobre boas infâncias}

\section{resumo}

Este artigo consiste em uma investigação inicial sobre o significado de uma boa infância baseado no ideal ético da autenticidade. Nesta introdução a uma filosofia da infância e autenticidade, o tema central é investigar como o ideal de autenticidade já está pressuposto no discurso contemporâneo sobre o que constitui uma boa infância. No emergente campo da filosofia da infância, as capacidades de agência, autonomia e comprometimento das crianças, assim como o papel fundamental dos pais em garantir possibilidades de exercer tais capacidades, vêm sendo cada vez mais destacadas, juntamente com um discurso de que existe um valor intrínseco da infância. Esses desenvolvimentos são paralelos às reconstruções contemporâneas da autenticidade como um ideal ético. Os debates atuais enfatizam a importância de uma pessoa encontrar, criar e construir sua originalidade e como realizá-la. Ao mesmo tempo, essa busca deve reconhecer as demandas que emanam de algo além do que desejos humanos: de sua cultura e comunidade. A dinâmica paralela entre esses dois discursos - filhos-pais e indivíduo-sociedade -

${ }^{1}$ E-mail: luizdovalle2@gmail.com 
authenticity as an inarticulate ideal in the contemporary discourse of good childhoods

aponta para uma direção em que a aplicação do conceito de autenticidade à construção de novas interpretações e práticas de uma boa infância pode trazer resultados frutíferos. Depois de examinar tais paralelos, algumas dessas práticas que emergem da equação de boa infância com infância autêntica são demonstradas, como a importância de cultivar os momentos de cuidado e compromisso das crianças e o desenvolvimento de projetos pessoais. $\mathrm{O}$ artigo conclui explorando algumas limitações da metodologia aplicada e como ela pode ser um ponto forte em pesquisas futuras sobre este tópico.

palavras-chave: infância; autenticidade; psicologia moral; projetos pessoais.

\section{la autenticidad como ideal inarticulado en el discurso contemporáneo sobre buenas infancias}

\section{resumen}

Este artículo consiste en una investigación inicial sobre el significado de una buena infancia siguiendo el ideal ético de la autenticidad. En esta introducción a una filosofía de la infancia y autenticidad, el tema central es investigar cómo el ideal de autenticidad ya se presupone en el discurso contemporáneo sobre lo que constituye una buena infancia. En el campo emergente de la filosofía de la infancia, se destacan cada vez más las capacidades de agencia, autonomía y compromiso de los niños y el papel fundamental de los padres en garantizar las posibilidades de ejercer tales capacidades, junto a un discurso de que existen unos bienes intrínsecos de la infancia. Estos desarrollos son paralelos a las reconstrucciones contemporáneas de la autenticidad como un ideal ético. Los debates actuales enfatizan la importancia de encontrar, crear y construir la propia originalidad y cómo realizarla. Al mismo tiempo, esta búsqueda debe reconocer demandas que emanan de algo más que los solos deseos humanos: de la propia cultura y comunidad. Las dinámicas paralelas entre estos dos discursos -hijos-padres e individuosociedad- apuntan en la dirección de que aplicar el concepto de autenticidad a la construcción de interpretaciones y prácticas novedosas de una buena infancia puede dar resultados fructíferos. Tras examinar tales paralelismos, se señalan algunas de estas prácticas que surgen del análisis de las buenas infancias como infancias auténticas, tales como la importancia de cultivar los momentos de cuidado y compromiso de los niños y el desarrollo de proyectos personales. El artículo concluye explorando algunas limitaciones de la metodología aplicada y cómo puede ser una fortaleza en futuras investigaciones sobre este tema.

palabras clave: infancia; autenticidad; psicología moral; proyectos personales. 
miranda

authenticity as an inarticulate ideal in the contemporary discourse of a good childhood

\section{introduction}

Philosophy of childhood has been recently emerging as a subfield of philosophy exploring philosophically relevant questions such as how children should be treated, what the capabilities of a child are, and what a good childhood means (Gheaus; Wispelaere, 2019). Research within this sub-field of philosophy tries to critically evaluate the contemporary concept of childhood, answering questions related to defining what a child is, how these definitions relate to understanding a good childhood and how these concepts change over time (Matthews; Mullin, 2018). Current works emphasize the intrinsic goods of childhood and how childhood can be understood not only as a preparatory stage for adulthood.

In these discussions, the authors highlight different capabilities of the children that were not previously considered, such as agency, care, commitments, and selfgovernance. The appearance of such capacities in discussions related to childhood are used to reconceptualize how ethically charged notions, such as "autonomy" and "responsibility," are manifested by children and how they are involved in defining a good childhood (e.g., Matthews, 1994; Betzler, 2015). In this current emerging sub-field of research on children's capacities and the intrinsic goods of childhood, I argue, there seems to be already a commitment to some notion of authenticity. Authenticity is preliminarily defined as the notion that something is good when it is true to itself.

Analyzing the ethical ideal of our contemporary age, authors such as Taylor (2007) and Guignon (2004) claim that the search for the ideal life has been more and more connected to the quest for an authentic way of living. From that perspective, these authors proclaim that we live in the "Age of Authenticity." Authenticity, however, is not a straightforward concept, and much philosophical work attempts to understand the meaning of such an ideal (Taylor, 1991; Guignon, 2004).

As mentioned above, the use of the term authenticity initially and preliminarily refers to something (or someone) that is "faithful to an original," "true to itself." This term, however, faces some complications when attributed to human beings. The question 
authenticity as an inarticulate ideal in the contemporary discourse of good childhoods

of what it means for people to be their authentic selves raises and presupposes different metaphysical and epistemological issues related to discussions about, among others, personal identity, agency, and free will.

One way to conceptualize an authentic person is as a person that thinks and acts following desires, motives, ideals, or beliefs that express who they really are. Posing the question of authenticity in this domain transforms the nature of the issue into moralpsychology and responsibility and defines authenticity as a matter of clarifying what consists of acting in this expressive manner (Varga; Guignon, 2020).

This conception of authenticity (as an ethical ideal) emphasizing the importance of the personal dimension in choosing and acting has suffered harsh criticism for allegedly leading to individualism and self-absorption (Lasch, 1979; Bloom, 1987). Present-day reconstructions of authenticity strive to go beyond these critiques of self-indulgence. These reconstructions formulate how social frameworks are constitutive elements of living authentically (Taylor, 1991). A recent formulation of authenticity along those lines can be found in Varga (2011), who identifies living authentically with caring and being committed to what matters to us, however, emphasizing that these commitments only make sense within an inter-subjectively constituted web of values and orientations (horizons of significance).

Children, however, do not express care in the same way as adults. Howbeit differently, even young children seem to present some kind of commitment (Mullin, 2007). If being authentic is understood as being committed in a way that expresses what we care about, to understand what it means for a child to be authentic, a crucial step is to understand in what ways children manifest care and commitments and how it relates to being authentic as a child.

In this paper, the main objective is to investigate how authenticity appears in the discourse of philosophy of childhood as an inarticulate ideal. A secondary aim is to analyze how articulating authenticity as a guiding notion for understanding a good childhood can alleviate some tensions present in such discourse and strengthen some positions in the philosophy of childhood. This discussion will explore the manifestation of different moral-psychological capacities by children, such as caring, committing, 
agency, autonomy, and how they relate to the ethics of authenticity, to open up further debates and research on such topics.

In the first part of the paper, I briefly explore the field of philosophy of childhood. This section begins with the origins of the philosophy of childhood through the works of Matthews and Mullin (2018) and Aries (1964). Furthermore, I clarify two leading debates in this field: the promotion of the intrinsic value of children and the tensions involved in such discourse (Brennan, 2014; Gheaus, 2015); and the discussion on children's moralpsychological capacities through the works of Mullin (2007; 2014) and Betzler (2015). By the end of this section, I will have completed a brief review of the sub-field of philosophy of childhood, and the first indications of an underlying ideal of authenticity present in such a discourse will be exposed.

In the second part of the paper, I carefully review the literature on the concept of authenticity. I start with the discussion with unrefined formulations of authenticity and the main criticism for considering it as an ethical ideal. Moreover, I explore how Taylor (1991) and Varga (2011) propose reformulations of this concept, avoiding those criticisms. From this review, I answer questions such as "What is the ideal of authenticity?" "What is the ethical importance of the notion of authenticity?" and "What are the moralpsychological presuppositions involved in contemporary reconstructions of authenticity?". This part provides the rest of the research with a more detailed concept of authenticity.

The third part of the paper starts with a closer analysis of the discourse on intrinsic goods of childhood and children's capacities to show how they presuppose an inarticulate ideal of authenticity. The following subsection deals with how articulating this ideal solves some internal tensions present in such a discourse. After this clarification, through the literature on children's moral-psychological capacities, I show different ways that children can manifest authenticity. The section ends with a discussion on the ethical dimensions of promoting children's authenticity.

The paper concludes with a summary of the arguments and the methodology used within its scope, a debate on how it fares concerning the field of philosophy of childhood, and what the limitations are of the methods used in this article for proposing an 
authenticity as an inarticulate ideal in the contemporary discourse of good childhoods

interpretation of a good childhood based on the concept of authenticity. This conclusion presents suggestions for the possible ways to further investigate and formulate childhood authenticity.

\section{childhood: intrinsic goods and capacities}

The fact that childhood is a separate life stage, and therefore the treatment and behavior towards children is/should be different than towards adults, is not as undeniable and straightforward as it appears to be in contemporary Western societies. It was only through the changes in the understanding of the self and society ranging from the 12th to the 15th century, i.e., the "discovery" and institutionalization of dimensions of self-reflection and interiority (Simms, 2008; Aries, 1962), that childhood started to be seen as not being able to take place in adults' lives, and thus should be protected from the dangers of the adult world, and nurtured to take part in this world later.

Phillip Aries (1962) brought about an even more recent change in the understanding of childhood. By tracking changes in the concept of childhood across the centuries, he made the public aware of how the notions of what a child and what a good childhood is, is both historically and culturally dependent (Matthews; Mullin, 2018). This notion of childhood as a variable concept opened up discussions on how to better conceive childhood as a life stage to be appropriate for our times.

The logic behind this theoretical treatment of the concept of childhood is that we are already engaged in differing relations with children, defined by our social, historical, and cultural context. At the same time, our situated context also contains inherent ethical ideals, as well as several other differing discourses trying to grasp different aspects of life. One of the tasks, then, of a philosophy of childhood - the task that this essay wants to partially highlight and fulfill - is to understand the connections between a contemporary interpretation of childhood with prominent ideas of a good life.

To every interpretation of childhood proposed there is an inherent notion of what is a good childhood and what are the conditions necessary for this to be achieved. The normative force of these notions, however, is not to be understood as excluding conditions for those childhoods that do not fit in this model, but to serve as a guide to 
identify situations in which practices related to childhood do not conform to ethical ideals and propose solutions to improve the quality of life of these children. These interpretations of a good childhood can vary from general indicators of well-being - such as food, health and clothing - through indicators related to the future life of children such as access to education - and, finally, to intrinsic goods of childhood - such as unstructured play, innocence and lack of significant responsibility (Brennan, 2014) ${ }^{2}$.

The increasing popularization of philosophical works dealing with questions related to the child qua child led to the emergence and popularization of the philosophy of childhood as a somewhat independent sub-field of philosophy. Although these discussions are not programmatically unified or monolithic, an influential philosophical thread opened and followed by authors such as Matthews (1994), Brennan (2014), Gheaus (2015), and Mullin (2007), is (I) that childhood should be understood as not only a preparatory stage for adulthood but as having value for itself and (II) that the nature of the child should not only be understood as lacking adult capacities. The idea of the good childhood related to this discourse, obviously related to the possibility of manifesting such capacities, since they are to some extent exclusively connected to this life stage, i.e., this is what makes childhood so special (Gheaus, 2015).

Following the first thread exposed above, a good childhood is conceived as having not only instrumental value but intrinsic value as well. These authors investigate and then conclude that there are necessary things for a good childhood that do not necessarily contribute to good adult life. Gheaus $(2015$, p. 40$)$ start this discussion motivated by the fact that:

[...] childhood nostalgia is common, and childhood is often represented as the golden age of one's life. Even adults who do not judge their own childhoods as good, are often longing for the sense of freshness, limitless possibilities, excitement and relative freedom from social expectations they had as children.

\footnotetext{
2 These interpretations, to some extent, represent children with average social conditions, with access to education and healthcare, etc. Furthermore, these ideas are inescapably produced by adults, since adults are the one discussing philosophically and sociologically. What is important to have in mind is that these are not to be universal essential definitions of (good) childhood, but contextual interpretations that can be discussed, partially improved and partially dismissed in order to apply them in different contexts, such as understanding the lives of marginalized children or those that share different values than the ones represented in this paper.
} 
authenticity as an inarticulate ideal in the contemporary discourse of good childhoods

Brennan (2014) further develops the discussion on the intrinsic goods of childhood in two ways. First, she argues about the role of parents in promoting these inherent goods. Parents should, in her view, educate children to make good choices and continuously verify how ready the children are for those. Furthermore, parents have the obligation of letting children "try-out" specific opportunities and finally "evaluate the trade-offs between what's good for the child now, as a child, and what's good for the child, in the future, as the adult he or she will become" (Brennan, 2014, p. 24). A second way that Brennan contributes to the discussion is in her illustration of a concrete list of childhood goods, including opportunities for imaginative play, innocence, lack of significant responsibility, contribution to the household and community, relationship with other children, etc.

Within this discourse on the promotion of children's goods, however, there is an apparent tension between the intrinsic and the instrumental goods. It looks like promoting one of these goods necessarily diminishes the importance of the other. This antagonism between these two dimensions of a good childhood creates difficulties in moral evaluations of children's rights and duties, as well as a unified conception of a good childhood. Furthermore, another tension involved in this antagonism is what the role of the parents in promoting these different goods is, i.e., the question about "how do we, as agents who act on behalf of children, balance things that are good for the child-aschild with the things that are good for the child-as-future-adult" (Brennan, 2014, p. 24).

The other thread involved in contemporary philosophical works on childhood evaluates different ethical and moral-psychological notions given recent empirical research and different emerging interpretations of childhood and child's capacities. This discussion deals with concepts like autonomy and responsibility to assert that "[...] children are capable of goal-directed behavior while still relatively young, and are agents in this minimal sense" (Matthews; Mullin, 2018, p. 1).

Bou-Habib and Olsaretti (2015, p. 27) investigating the consequences of a developmental approach to autonomy claim that "[...] even fairly young children, may then be said to possess some degree of autonomy, understood as the effective ability to act in line with one's commitments, and that fact has some significance for how they may 
be treated". It is the case because, for some kinds of situations, children indeed can undertake means-ends reasoning, make some logical inferences, can appreciate something's value, have commitments, and sufficient strength of will. These situations are most related to children's engagement in personal plans or desired activity or moments of affection towards beloved people.

Monika Betzler (2015) argues that children's autonomy is strictly linked to their capacity to care. Even 2-year-old children, she argues, can express caring when, for example, they try to comfort their mother. This care involves the connection of a series of emotional attitudes by some kind of object, person, or state of affairs. It is through the positive reinforcement of such perspectives that autonomy can be cultivated. Children, therefore, should be motivated to follow personal projects such as hobbies and lasting social relationships to deepen their understanding of valuing, caring, and committing.

Mullin (2007), in a similar way, argues that children's ability for caring expresses some kind of autonomy. She argues that through understanding the value of long-lasting relationships of love, children can express their initial manifestations of agency through meaningfully acting with a goal towards or with this valued person in mind. She argues that these autonomous actions are manifested, for example, when:

Children seek to give in a variety of ways, as they may smile at those they care about, try to give reassurance or physical comfort to someone who appears sad or hurt, give found objects like flowers or pretty rocks, draw pictures, sing songs or put on shows, listen closely to someone when he or she talks, and try hard at tasks because others have asked them to attempt them or take pleasure in their success. (Mullin, 2007, p. 543)

Thus, contemporary philosophical work, through the increasing investigation of children's capacities, has argued more and more that children indeed can care and commit to different people, objects, and states of affairs, therefore manifesting some kind of autonomy for their actions. This search for children's ability to care and commitment, together with the promulgation of different ways that childhood is intrinsically good, i.e., that a good "for itself," seems to manifest some kind of understanding of authenticity as an ethical ideal. The following section will explore the meaning of such an ideal before resuming the discussion on childhood and authenticity in the last chapter. 
authenticity as an inarticulate ideal in the contemporary discourse of good childhoods

\section{the age of authenticity}

authenticity as an ethical ideal

Within the dialectics between Enlightenment and Romanticism, aligned with a series of changes in the understanding of society and the self, emerges the idea of authenticity. Both the appearance of an "internalized self," the promulgation of freedom and autonomy, and the romantic call for self-expression opened up the possibility for a new understanding of a good life: a life in which one can search inside oneself for their aspirations and follow these dreams to be a fulfilled person (Taylor, 1989, 1991; Trilling, 1972).

In the nineteenth century, this ideal was opened up as a possibility. But it was in the last 70 years that it grew to dominate the western world, strictly aligning the ethical life with self-fulfillment, with living authentically. Even though some claim that attending to the call of this moral ideal has led to many of the great conquests of the contemporary world (e.g., technological advancements and personal freedom), others see it as a perverse ideal, since following it supposedly leads to individualism and selfindulgence (Taylor, 1989).

The critique of authenticity develops from the notion that the focus on one's inner feelings, desires, and aspirations can create tensions with rational deliberation, compassionate actions, and immersion into some kind of higher good, i.e., following authenticity leads to an increase of self-centered behavior and decrease of empathetic skills (Lasch, 1979; Bloom, 1987). Another set of criticisms refers to the metaphysics of authenticity. Authenticity's call to "Being true to oneself" seems to presuppose the existence of an essential "true inner self," a stable identity, whose properties are accessible through some kind of introspection (Bialystok, 2014; Rorty, 1989).

Contemporary interpretations of the notion of authenticity strive to go beyond these two criticisms. Authors such as Taylor (1989; 1991), Golomb (1995), and Guignon (2004) answer the first kind of criticisms by emphasizing the inherently social and selftranscendent dimensions of authenticity. In a parallel effort, Varga $(2011 ; 2015)$ and Bauer (2017) develop a more moral-psychological notion of authenticity, drawing from works of Harry Frankfurt (e.g., 1998; 2006) on self-expression, care, and commitments, therefore, 
avoiding some of the criticized metaphysical complications. Based mainly on the works of Taylor and Varga, I will sketch the concept of authenticity to be used for the rest of the paper.

Before diving into Taylor's discussion on articulating the notion of authenticity as a proper ethical ideal, it is worth it to briefly discuss what an ethical ideal means in his philosophy. In "The Ethics of Authenticity," Taylor (1991, p. 16) states: "what do I mean by a moral ideal? I mean a picture of what a better or higher mode of life would be, where 'better' and 'higher' are defined not in terms of what we happen to desire or need but offer a standard of what we ought to desire."

For Taylor (2007), therefore, implying that we live in the "age of authenticity" means that the pursuit of authenticity pushes people into pursuing a set of choices. These choices deeply define the outlook of the life and experience of people living in contemporary times. In Taylor's writings, the debate is precisely how to interpret and promulgate better such an ideal to surpass the criticisms above.

Taylor starts his hermeneutic move with a definition of this culture of authenticity that could be summarized in the following quote:

I mean the understanding of life which emerges with the Romantic expressivism of the late-eighteenth century, that each one of us has his/her own way of realizing our humanity, and that it is important to find and live out one's own, as against surrendering to conformity with a model imposed on us from outside, by society, or the previous generation, or religious or political authority. (Taylor, 2007, p. 475)

This formulation of authenticity indeed appears to be subject to the criticisms above. However, Taylor (1991, p. 35) claims that if the presuppositions of such an ideal are investigated, i.e., what are the conditions of realization of such an ideal and what this realization would look like, it is possible to conclude that "[...] modes [of authenticity] that opt for self-fulfillment without regard (a) to the demands of our ties with others or (b) to demands of any kind emanating from something more or other than human desires or aspirations are self-defeating."

His arguments go in the following direction: determining what is essential, significant for us is necessary for our pursuit of originality and self-fulfillment, and such significance only holds its importance within a background of intersubjectively shared 
authenticity as an inarticulate ideal in the contemporary discourse of good childhoods

values, a horizon of significance. However, an individual does not choose these values and significance; they are embedded in one's culture, community, society, etc. To choose authentically, one must be attuned to this higher picture of what is valued, to the demands of society, to what matters given one's shared history, nature, and community.

Furthermore, besides searching for what is essential and significant for one's fulfillment, a person must also actualize these ideals to build this kind of identity to be or not authentic. Taylor asserts that the establishment of such an identity is dependent on negotiations, dialogues with others. He claims, therefore, that individualist conducts fall short of the ideal of authenticity, as they exclude the participation of dialogical relations necessary for identity formation.

Having in mind the discussions mentioned above, Taylor's (1991, p. 66) position can be briefly summarized in the following excerpt:

Briefly, we can say that authenticity (A) involves (i) creation and construction as well as discovery, (ii) originality, and frequently (iii) opposition to the rules of society and even potentially to what we recognize as morality. But it is also true, as we saw, that it (B) requires (i) openness to horizons of significance (for otherwise the creation loses the background that can save it from insignificance) and (ii) a self-definition in dialogue. That these demands may be in tension has to be allowed. But what must be wrong is a simple privileging of one over the other, of (A), say, at the expense of (B), or vice versa.

Varga (2011), attentive to Taylor's call and proposal of a healthy and thorough articulation of the concept of authenticity, formulates authenticity in a way to overcome both sets of criticisms. His discussion more connected to the moral-psychological dimensions of authenticity starts from the following understanding:

As a first rough approximation, we deploy the term when describing a person who acts in a way that we think of as faithful to herself and her principles. Such a person acts on impulses and ideals that are not only hers (as bearing her authorship), but that are also expressions of who she really is. (Varga, 2011, p. 2)

To go further from this preliminary definition, Varga calls upon the concept of "wholeheartedness." He formulates being authentic as being wholeheartedly related to one's commitments. This wholehearted engagement in life means the engagement in being committed to thoughts, reasons, desires, projects that are so fundamental for one's self-understanding that betraying them would mean betraying oneself. 
These wholehearted commitments involve full responsibility for the projects involved. They have to be central to one's life. Furthermore, this kind of commitment must be long-lasting; a person must continuously feel moved by the value of caring for such a life project and understanding (Frankfurt, 1988).

Varga goes further in his analysis of the structure of wholeheartedness, bringing his definition of authenticity closer to the ideals identified by Taylor (1991). His study of the framework of wholeheartedly caring reveals that this kind of caring is only possible if it is attuned to some public good, some self-transcendent value. He argues that the only way for these commitments to be continuously cared about, and therefore having a normative grip on us, is if the motivational element of some commitment comes from within and from an external field or background.

Moreover, when our desires seem to push our actions away from these commitments, the self-transcendent normative force of such commitments keep our acts within the passions and ideals related to such a commitment. Without this more-thanself value of such commitments, the continuity of wholeheartedly caring would not be possible, as the contingency of our desires would betray our will to be authentic.

This relation between our commitments and the public value towards which the commitment must be attuned is not one of reproduction. Our acts motivated by them at the same time articulate this public value. Our authentic actions are what sustains the horizons of significance of our and others being authentic. In this sense, formulating authenticity both in moral-psychological terms and considering its relation to others and self-transcending values, Varga can answer both types of criticism raised above.

Summing up the discussion on authenticity, being authentic can be understood as having a wholehearted commitment to what matters to us (independently of the content of such commitment). However, this unconditional caring is only possible if these commitments are attuned to self-transcending values. They carry a motivational force that is essential for the continuity of such commitments. 
authenticity as an inarticulate ideal in the contemporary discourse of good childhoods

\section{the ethics of authenticity}

The previous discussion of the moral-psychological structure of being authentic initially indicates the ethical value of authenticity. This subsection will explore three ways to be authentic overlaps and influences living a moral life, i.e., a life attuned by some kind of public good, attentive to others, and responsibility for one's acts. The first aspect of such a relation between ethics and authenticity has already been pointed out in the last section: the motivational element of wholehearted commitments.

This motivational element for doing actions committed to the public good differentiates ethical models based on authenticity from other concepts with similar philosophical baggage. Being authentic, in this way, can answer the problem that ethical theories focusing on personal autonomy and the self-choosing of moral laws typically face, i.e., the issue of why such actors would care to maintain or to act under such moral law.

Since the laws, projects, and commitments chosen in the light of authenticity are (I) attuned to public values and (II) resonate with a person's innermost and ownmost feelings, desires, and understandings, following these laws, projects, and commitments automatically have a normative weight for the actor. Acting according to this attunement between inner and outer motivational elements that sustains the continuity of these commitments influences people to favor this communal good, as doing otherwise risks the disassembling of one's self-understanding.

The second relation of authenticity to a more ethical life concerns the openness that the search for authenticity induces towards others and the social world. In the sense that the formation of authentic commitments presupposes a dialogical relation with the other and towards the world, cultivating a healthy model of authenticity leads to a deeper engagement towards the world and the needs of others (Varga; Guignon, 2020).

Following this Taylorian view of authenticity, therefore, leads to different kinds of dialogical relations, relations such as mutual recognition of difference, i.e., a universal recognition that everyone must follow their understanding of the good (embedded in the horizons of significance as mentioned above) and the development, then, of relations of identification of commonalities between different values. The second way that this 
dialogical dimension of authenticity influences our connection to others is the way we build our intimate relationships. Relationships that define our wholehearted commitments must go beyond instrumental value. They cannot be dispensable. If these relationships will define us, they (or their effects) must be long-lasting and thus carefully cultivated and developed (Taylor, 1991).

The last dimension of the relation between authentic and ethical life that I want to point out is responsibility. Our acts, thoughts, and identity in general, when stemming wholeheartedly from our care and commitments, are entirely our own. They reflect, thus, "who we really are," what makes us wholly responsible for them, as we do not incline to change them (Varga, 2015.).

The other two dimensions can be seen as different manifestations of this third dimension of responsibility, as being an authentic person comprises 'responsibility for one's own self, being true to one's own convictions, beliefs, ideals, life-plans, and projects; being truthful "toward oneself and about oneself in word and deed,"' as well as "taking moral responsibility for one's actions and any active contribution to one's selfconstitution; transgressing an exclusively personal perspective; being a trustworthy partner of social interaction" (Bauer, 2017, p. 13).

In summary, leading an authentic life leads to a more responsible engagement with both the social world, through the necessity of attunement to the public good; the others, exemplified by the need of trustworthy relationships and mutual recognition in the development of an authentic identity; and one's self, as the thoughts and acts emanating from this person are much more closely relatable and attributable to who they truly are.

\section{childhood and authenticity}

inarticulate authenticity

After the brief survey of the field of philosophy of childhood and the exposition of contemporary reconstructions of authenticity, in this subsection, I more thoroughly explore the works of Brennan (2014), Gheaus (2015), Betzler (2014), and Mullin (2007; 
authenticity as an inarticulate ideal in the contemporary discourse of good childhoods

2014). With this exploration, I want to show how the concept of authenticity is already implicit in the discourse of philosophy of childhood and point the directions of an argument about how articulating such ideals can help alleviate some of the tensions delineated above.

There is a preliminary way in which the discourse on intrinsic goods of childhood already expresses a commitment to authenticity. This can be simply conceived as the mere fact of the possibility of discourse about those inherent goods. If authenticity wouldn't be already implied as an ideal (to any extent), it would be impossible to articulate such a notion of intrinsic good, since a good childhood would have to be linked to an instrumental good, and therefore not good in itself, as a separate life stage, with particular features.

Even though the articulation of the notion that an intrinsically good childhood is linked to the idea of "being true to itself," and therefore to authenticity, seems selfevident and too broad, it makes possible the question of what are the more precise ways that this notion is implicit in such a discourse. There are two ways in which this ideal is more ingrained than assumed above: (I) in the idea that children should try on and express different interests towards the world, and that the parents should respect this, but (II) that nevertheless, parents have a role in mediating and motivating meaningful activities.

This first thread can also be approached by the idea that children should express themselves by experimenting with different choices through "imagination, sense of curiosity and wonder, to exercise their capacity to enjoy new things, people and ideas and to have a care-free attitude." (Gheaus, 2015, p. 45). Children should explore the world freely to discover and cultivate different capacities they might have.

Brennan (2014), with the same ideal in mind, manifests this thread through her discussion of the importance of the children's interest in the determination of childhood's goods. She advocates for providing a wealth of options to the children, thus opening up a rich and diverse life, with particular attention to reading the pleasure such activities give to the children (as their intrinsic interest) and how they forge the parent-child relation. 
Moreover, Mullin (2014) argues for providing children with different situations to manifest their goals, desires and cares for their exploration outcomes. Parents should thus recognize children's decisions and actions as a manifestation of the children's engagement and support them in a trade-off between child's satisfaction, meaningfulness for the child, and relation to communal values. In this sense, children can find meaningful activities for themselves and the community.

As discussed in the last section, authenticity involves creating, constructing, and discovering what we hold as meaningful, given our capacities for expression and interacting with our surroundings. This first thread of similarity between the promotion of the intrinsic goods of childhood and the ideal of authenticity manifest this exact similar trend: children should explore different activities and capacities through their way of interacting with the world (imaginative skills, care-free attitude, among others) to create and develop a sense of meaningfulness towards others and the community.

The second manner authenticity is presupposed in this discourse exposed above concerns the role of the parents in adjudicating, motivating, and promoting the manifestation of children's expressive actions. This role reflects Taylor's (1991, p. 35) second horn of his conditions of authenticity, “(B) requires (i) openness to horizons of significance (for otherwise the creation loses the background that can save it from insignificance) and (ii) a self-definition in dialogue." Parents, in this sense, have the right and obligation to serve as the source of dialogue and significance for children's manifestations of autonomy and authenticity.

Brennan (2014) manifests this view by discussing parents' rights and obligations of respecting children's interests. In her opinion, parents should let children try out different choices. Through dialogues with the children, parents should reach a trade-off between how to manage these interests as something good for the child now and what's suitable for the child in the future.

Similarly, Mullin (2014, p. 6) highlights the role of parents towards children's expressions and interests. She argues for the dialogical relationship between parents and children so the children can find motivation and significance for their expression, i.e., it involves: 
authenticity as an inarticulate ideal in the contemporary discourse of good childhoods

[...] adults' showing interest in children's perspectives, providing clear information about what is expected and why outcomes can be endorsed from those perspectives, and a willingness to be responsive to children's interests and perspective in terms of how the outcome is to be achieved and why it is valuable.

This kind of relationship, she claims, contributes to "increasing children's tendency to find the goals of those in their community to be personally meaningful" (Mullin, 2014, p. 7). This dialogue between parents and children should permit the exchange of views and respect for the children's care and commitments, achieving an understanding of the child's perspective and explaining that of the adult. In this way, the parents can support children to have long-lasting, authentic care and commitments attuned to the communal web of significance. Mullin concludes that this kind of approach is the only justifiable kind of paternalistic intervention.

Betzler (2015) argues that parents should guide children's projects towards being attuned to conceptions of the good and understanding shared values. By providing opportunities for children to value personal projects and sustain them over time, parents can help children manifest stable caring for different objects, people, and states of affairs and develop some sense of self-understanding. The role of the parents involves:

[...] taking an interest in what children care about, encourage them in pursuing what they care about, empathizing with them if what they care about gives rise to frustration, giving them critical feedback if what they care about is imprudent, immoral, or otherwise of disvalue, and helping them understand when their emotions are appropriate and their caring directed to something valuable. (Betzler, 2015, p. 75)

The works of Betzler (2015) and Mullin (2014) not only exemplify the second thread of the presence of the ideal of authenticity but initiate the discussion on the actual manifestation of children's authenticity through personal projects, care, and commitments. But before moving to this discussion, in the following subsection, I will evaluate some consequences of acknowledging the ideal of authenticity in the contemporary discourse of a good childhood and how it solves some of the tensions pointed out in the first section. 


\section{authenticity as an ideal for a good childhood}

In the last section, I highlighted some of the dimensions of authenticity manifested in the current discourse on an (intrinsically) good childhood. Articulating this presupposed ideal might have the potential to solve some of the tension contained in this discourse: first, the fact that paternalistic intervention on children's interest must be justifiable (are not constitutive of these goods), and second, the apparent incompatibility between instrumental and intrinsic goods of childhood.

The discussion so far in contemporary works of philosophy of childhood, at its core, proposes that the interests, opinions, choices, and desires of children must be respected and taken into consideration (Matthews; Mullin, 2018). On the other hand, there are cases in which parents should interfere, sometimes against the children's will, motivated by the avoidance of some immediate harm, or for the sake of their future lives. Therefore, even when proposing these intrinsic goods, there must be recommended times in which paternalism is justifiable, i.e., that these intrinsic goods must be overridden. Part of Mullin's (2007; 2014) and Brennan's (2014) work is a search for the moments in which paternalistic interventions are desirable and how they, in some ways, do not conflict with these goods.

Another tension that I briefly exposed in the first section is between the intrinsic and the instrumental goods of children. It looks like if one of these kinds of goods is to be promoted, it is at the cost of the other. In the sense that what is good for the child as a child is in opposition to what is suitable for the child as a future adult. This thread is apparent, for example, in the following passage by Brennan (2014, p. 24): “An important question facing parents is how do we, as agents who act on behalf of children, balance things that are good for the child-as-child with the things that are good for the child-asfuture-adult?"

Given these tensions in current interpretations of a good childhood, I propose that they are only present because the concept of authenticity underlying these ideas is not fully articulated. Establishing a framework for a good childhood based on the idea of authenticity can and should (I) solve these tensions posed above, (II) incorporate this 
authenticity as an inarticulate ideal in the contemporary discourse of good childhoods

novel research on children's moral psychology to illustrate child's authenticity, and (III) clarify the ethics related to such a position.

Thus, basing a good childhood in promoting authenticity consists of following such a story: a good childhood is one in which children realize their intrinsic capacities, try out different projects, choices, and can express care and commitments. These manifestations, however, only make sense through dialogue with the parents and their support, as only through the motivation provided by this dialogue that children can feel the significance of their actions, and therefore feel the manifestation of their capacities recognized.

However, the promotion of these expressions from the child's side through parental encouragement and empathizing with these pursuits does not necessarily prioritize any of the two dimensions of childhood - child qua child or child qua future adult - but can serve as a manifestation of both. When the child expresses their desires and interest, and when these interests can be motivated by the parents for being meaningful concerning an understanding of the public good, the child not only has their intrinsic goods respected and promulgated but at the same time develops a sense of autonomy (Mullin, 2007; 2014) and authenticity, valuing, acquisition of knowledge of its backgrounds and self-understanding, i.e., also serves as achieving instrumental goods.

Therefore, following this understanding of a good childhood as an authentic childhood, the tensions of paternalism are relieved as parental intervention is interpreted as part of the movement sustaining the significance of those intrinsic and instrumental goods $^{3}$. In other words, good parental/paternal interventions are conceived as those that help develop children's interests, happiness and self-fulfillment, by addressing their interests in play and imagination. Also, the antagonism between the two interpretations of childhood goods melts as these kinds of authentic manifestations are to be promoted. A closer look at how children can express this authenticity, given their moral psychology, is the subject of the following subsection.

\footnotetext{
${ }^{3}$ For a similar, but more detailed discussion about paternalism and children's intrinsic goods, see Alexander Bagattini's "Future-Oriented Paternalism and the Intrinsic Goods of Childhood" (BAGATTINI, 2016).
} 


\section{children's moral-psychology and authenticity}

As discussed in the second section, a contemporary turn on discussions of authenticity is to pose it in terms of moral psychology to avoid some metaphysical complications. Varga (2011) identified living authentically with having cares and commitments, of the kind that are expressive of what matters to us. For these manifestations to be continuous, they must be tuned to some shared values.

Furthermore, as the discussion in the preceding sections shows, children can care for and value projects, people, and objects under certain situations and conditions. This subsection will explore these different situations to illustrate how this promotion and cultivation of such capacities relate to children's authenticity and how they are manifested. I discuss two cases: care for loved ones and personal projects.

The first way that children can manifest authenticity is through relationships of love. Their manifestations of caring for loved ones (as the example of a 2-year-old comforting their sad mother) does not constitute a momentary, temporary impulse, but the expression of a long-lasting positive, caring disposition towards the people constantly surrounding them (Betzler, 2015).

This feedback between expressions of love and reinforcement can be a source of volitional stability for children, i.e., the source of continuity and stability of what the self cares about. Mullin (2007, p. 543) exemplifies it with the following passage:

[...] the fact that the boy cares about his [grieving] father and that this is part of his stable volitional nature is shown in his attentiveness to his father's emotions, in his willingness to leave behind a source of enjoyment to comfort his father, in his ability to alter his demands to reflect the importance he gives to his father's happiness [...].

Through this dialogical relation between children's expressions and parental approval, manifestations of authenticity can scaffold on this relation of dialogue and recognition, amplifying the range of their caring and their goals. Mullin (2014, p. 4) stresses that:

For many children, goals in this sense can include the well being of those they love, the ability to continue relationships with friends and loved ones, keeping prized possessions, engaging in favourite activities, feeling pleasure, pleasurable excitement, and feeling comfortable and at ease, 
authenticity as an inarticulate ideal in the contemporary discourse of good childhoods

mastering new and challenging tasks, being recognized for skills and accomplishments, and avoiding significant stress and pain.

Betzler (2015) argues that through parental encouragement and empathizing with these pursuits, children can understand what is valuable and draw motivation from these worthy projects and commitments. Mullin (2014), complementarily, poses that these manifestations of care help children develop self-control and the rationale for activities that necessitate hard work and risk of failure.

In the range of older children, through the scaffold of caring relationships, authentically valuing and committing can be expressed by engaging in long-lasting recurring personal projects. By taking part in such private projects, children can manifest their interests and intrinsic capacities, social, play, and imaginative skills (Mullin, 2007) while solidifying values, webs of significance, and understanding what is crucial for them and the ability to commit over time.

According to Betzler, personal projects consist of norm-governed goals. They are constituted by changing emotions and actions that affect the person pursuing them while these goals express an identity-constituting commitment. Some examples are hobbies, friendships, political activities, sports, crafts, and art enterprises. Through participation in such projects, children manifest their interests and desires in a way that expresses themselves and makes them identify themselves with their activity since part of being inserted in such a project is being emotionally vulnerable to how the project fares.

Furthermore, the norms that govern such a project, and therefore give value to the activities, are socially determined, which provides the children with insertion in an intersubjective web of significance that speaks to them. In this sense, children experience various ways in which aesthetic, social, nature-related, technical, intellectual properties are valuable and how these values are related to the children's emotions, knowledge, and identity.

Since parents are acquainted the most with the dispositions and preferences of their children, they should provide them with opportunities to try them out and encourage this pursuit by taking an interest in the children's engagement in such a project. In this way, they can bridge the gap between children's motivation and the 
external motivation of the value of such a project by exchanging ideas about these evaluative properties and how to pursue them (Betzler, 2015).

In summary, there are many ways that children can express themselves authentically, starting through relationships of love and care towards caregivers and prized objects as young as two years old, and further in life as engagements in personal projects such as hobbies and recurring activities. If a good childhood in the age of authenticity can be interpreted as an authentic childhood, then for the good of their children (intrinsic and instrumental), parents should promote, motivate and incentivize these kinds of moments and activities.

\section{the ethics of authentic children}

Finally, after exploring the general advantages of using authenticity as a framework for a good childhood, and the actual possibilities of authentic moments from the children, I want to point out some ways in which the ethics of authenticity also applies to children, i.e., in what ways being an authentic child makes them a good child and a good person. I briefly expose three lines of argument on how this discussion can be followed: the parent-child relationship, children and agency, and the meaningfulness of childhood.

The first kind of argument has already been discussed in the former subsections. For children to be authentic, they need to recognize how their interests and actions are valuable under a self-transcending ethical idea. For this condition to be met, children and parents must have a close relationship. This relation has to enable the parents to recognize the children's talents and interests and serve as a motivation for the children and a connection between the children's projects and communal values.

This close dialogical relationship between children and parents constricts the action of both parties. Concerning parents, actions that undermine children's expressions and the manifestation of agency and interests that go against this ideal for childhood should be constrained. At the same time, children's self-emerging projects and plans should be evaluated and motivated in the case of being related to a communal good or the development of shared values. 
authenticity as an inarticulate ideal in the contemporary discourse of good childhoods

The second ethical dimension of an authentic childhood relates to the sense of agency. When acting authentically, in the meaning posed above, children are, to some extent, autonomous agents. Authentic children, therefore, can feel like actors in the world, able to cause transformative action. When attuned and motivated to some understanding of the good, these children can be considered as persons capable of a moral act.

A consequence of such a capacity of children to exercise moral acts (through the dimensions of agency and autonomy inherent in their authentic actions) is subject to some kind of responsibility responses ${ }^{4}$. By reflecting on the children's cares and commitments, these acts elicit some responses from moral agents. Thus, reflection on children's authenticity can help elucidate the issue of to what extent children can be considered moral agents ${ }^{5}$. For example, it can be related to the discussion of moral responses to varying kinds of responsibilities under different conditions is present, for example, in Shoemaker's (2015) tripartite theory of moral responsibility.

While this possibility of autonomy, agency, and responsibility is present if children can be seen as capable of authentic acts, the option of including children as political actors and participants in the community's life is also open. While on the other hand, an interpretation of a good childhood defends the children's interests, capacities, and intrinsic goods. It also opens up the possibility of special responsibility and participatory role of children.

The third thread of discussion I would like to open up as an ethical consequence of childhood authenticity is the experience of meaningfulness that children can experience. By both having the feeling of agency and autonomy towards their actions and choices and the understanding that these actions are recognizable as good by their parents or their communities, children can have a sense that their life is and can be meaningful.

\footnotetext{
${ }^{4}$ Shoemaker (2015) asserts that there is a different set of reponses that we manifest when holding someone responsible, including praise, blame, pride, shame, approval, disapproval, anger, regret, etc. He argues that people manifest different kinds of responsibility responses to different moral agents, and these reponses can and should be normatively judged according to the moral capacities of the agent in question.

${ }^{5}$ For a discussion on children as moral agents, see Traina (2009).
} 
Instead of indifferently going about their formative years (which will be a future source of nostalgia) following parents' forced choices, the children I imagine here, i.e., good childhoods following the contemporary ideal of authenticity, are children that fulfill these years with meaningful activities. Through the expression of their interest and choices and the cultivation of sensibilities for community values, these authentic children, since childhood, start establishing their position in their communities, are capable of dialogical relations, holding long-lasting, identity formation projects and commitments, and, finally, are capable of participatory and transformative changes in their surroundings. There is an excellent chance that these children indeed develop meaningful lives and continue to live up to the ideal of authenticity.

\section{conclusion}

In this paper, I evaluated how the ideal of authenticity is already presupposed in the discourse on intrinsic goods of childhood and the children's capacities and pointed out various discussions that are opened up by articulating such an ideal. Before concluding the article, some final remarks are left to sum up the debate and serve as initial steps for future discussion on such topics.

Firstly, I want to go back to Taylor's notion of a moral ideal to better understand the role of the concept of authenticity in the discussions of childhood. In his view, this kind of ideal means a picture of what a better or higher mode of life would be, standards of what should be desired. If this kind of ideal is translated towards discussions of good childhood - instead of good life - and taking into consideration that the readers and debaters of such topics are parents and other adults interested in the well-being of children, authenticity as an ethical ideal for a good childhood means an interpretation of what a good childhood would be, proposing "better" and "higher" standards of how to treat children, and how to intervene (or not intervene) in the life of the little ones.

Considering this idea of ethical ideal of a good childhood, the discussions above point to the following set of standards to be promoted: (I) Parents should be attentive and should protect children's interests, expressions, manifestations of care, and love; (II) From the knowledge of such interests and dispositions, they should motivate children to 
authenticity as an inarticulate ideal in the contemporary discourse of good childhoods

maintain relationships of love and friendship, as well as engage in personal projects, such as hobbies and long-lasting activities; (III) It is only through the recognition of the child, through the intervention of their caretakers, that they can experience how their actions, interests, and choices are connected to self-transcending (communal) values, that give meaning to such an activity.

Following up on this ideal, as discussed above, solve some tensions involved in different proposals of understanding a good childhood, such as the necessity of justification for parental intervention in children's well-being and the tensions between the trade-offs between children's intrinsic and instrumental goods. Furthermore, articulating and following this ideal brings with itself an ethical import that fits contemporary demands and understanding of the good. Authentic children have the opportunity of a more dialogical relation with their parents, a higher sense of autonomy and transformative and participatory power towards the world, and a sense of meaningfulness in their lives.

In one sense, this work successfully achieved its goal of being a work in the philosophy of childhood by continuing this field's thread of emphasizing the necessity of respecting children's interests and capacities and the intrinsic goods of childhood. However, it is clear that the treatment of authenticity is taken from an adult's perspective, and therefore to some extent, fails to propose a way of understanding children's authenticity uniquely.

I believe that this is not a fatal flaw in this work. As involved in a hermeneutical methodology between reciprocal updating definitions of a good childhood and authenticity, given the current position in the hermeneutical circle, this is a preliminary step towards a more authentic conceptualization of authenticity from a perspective closer to the children. This paper opens up the possibility of such a discourse and such a conceptualization.

This previous remark begins to illustrate the possibilities for future research. The first suggestion for such future research is a more thorough elaboration of one of the topics discussed in the previous section, for example, a more detailed investigation of children's moral-psychology in connection to authenticity to reveal different ways that 
children can be authentic. Another way to conceive these future directions is as ethical debates on the worth of considering this ideal of authenticity towards children, i.e., following up some ethical threads I pointed out in the last part of the previous section.

Another fruitful discussion emerging from the considerations of this article is on education. When understanding authenticity from the dimension of children as future adults, it is clear that education plays a role in this preparation towards authentic adulthood. Therefore, conceiving authenticity as an educational aim could also open up discussions, solutions, and practical possibilities in a different philosophy and social sciences field.

Authenticity is a dominating concept in the contemporary western world. We strive to fulfill ourselves concerning our innermost desires, care, and commitments. Perhaps this fulfillment and meaningfulness brought about by these practices of authenticity are not only for our sake as autonomous adults. I tried to point out, argue and defend, that children are conceivable as possible authentic individuals and that this possibility should be promoted for their own sake, for ours, and for the sake of better communities.

\section{references}

Ariès, Phillipe. Centuries of Childhood. New York: Random House, 1962.

Bagattini, Alexander. Future-Oriented Paternalism and the Intrinsic Goods of Childhood. In: Bagattini, Alexander; Macleod, Colin (eds). The Nature of Children's Well-Being. Theory and Practice. Dordrecht: Springer, 2015. p. 17-33.

BaueR, Katharina. To be or Not to be Authentic. In Defense of Authenticity as an Ethical Ideal. Ethical Theory and Moral Practice, v. 20, n. 3, p. 567-580, Mar./Jun. 2017.

Betzler, Monika. Enhancing the Capacity for Autonomy: What Parents Owe Their Children to Make Their Lives Go Well. In: Bagattini, Alexander; Macleod, Colin (eds). The Nature of Children's Well-Being. Theory and Practice. Dordrecht: Springer, 2015. p. 65-84.

Bialystok, Lauren. Authenticity and the Limits of Philosophy. Dialogue, v. 53, n. 2, p. 271-298, Jan./Jun. 2014.

Bloom, Allan. The Closing of the American Mind. New York: Simon and Schuster, 1987.

Bou-Habib, Paul.; Olsaretti, Serena. Autonomy and Children's Well-Being. In: Bagattini, Alexander; Macleod, Colin (eds). The Nature of Children's Well-Being. Theory and Practice. Dordrecht: Springer, 2015. p. 15-33.

Brennan, Samantha. The Goods of Childhood and Children's Rights. In: Baylis, Francoise; Mcleod, Colin (eds.). Family-Making: Contemporary Ethical Challenges, Oxford: Oxford University Press, 2014, p. 29-47. 
authenticity as an inarticulate ideal in the contemporary discourse of good childhoods

Frankfurt, Harry. The Importance of What We Care About. Cambridge, Cambridge University Press, 1988.

Frankfurt, Harry. Taking Ourselves Seriously and Getting it Right. Stanford: Stanford University Press, 2006.

Gheaus, Anca. The 'Intrinsic Goods of Childhood' and the Just Society. In: Bagattini, Alexander; Macleod, Colin (eds). The Nature of Children's Well-Being. Theory and Practice. Dordrecht: Springer, 2015. p. 35-52.

Gheaus, Anca; Wispelaere, Jurgen. The Routledge Handbook of the Philosophy of Childhood and Children. Abingdon: Routledge, 2019.

Golomb, Jacob. In Search of Authenticity from Kierkegaard to Camus. London and New York: Routledge, 1995.

Guignon, Charles. On Being Authentic. London: Routledge, 2004.

Lasch, Cristopher. The Culture of Narcissism: American Life in an Age of Diminishing Expectations. New York: Norton, 1979.

Matthews, Gareth. Philosophy and the Young Child. Cambridge and London: Harvard University Press, 1980.

Matthews, Gareth. The Philosophy of Childhood. Cambridge: Harvard University Press, 1994

Matthews, Gareth.; Mullin, Amy. The Philosophy of Childhood. Stanford Encyclopedia of Philosophy, oct. 2018. Available at <https://plato.stanford.edu/entries/childhood>. Accessed on: August 30th, 2020.

Mullin, Amy. Children, Autonomy and Care. Journal of Social Philosophy, v. 38, n. 4, p. 536-553, Nov. 2007

Mullin, Amy. Children, paternalism and the development of autonomy. Ethical Theory and Moral Practice, v. 17, n. 3, p. 413-426, Aug. 2013/Jun. 2014.

Rorty, Richard. Contingency, Irony and Solidarity. Cambridge: Cambridge University Press, 1989.

Shoemaker, David. Responsibility From the Margins. Oxford: Oxford University Press, 2015

Simms, Eva. The child in the world: Embodiment, time, and language in early childhood. Detroit Wayne State University Press, 2008.

Taylor, Charles. Sources of the Self. The Making of the Modern Identity. Cambridge: Cambridge University Press, 1989.

Taylor, Charles. The Ethics of Authenticity. Cambridge: Harvard University Press, 1991.

Taylor, Charles. A Secular Age. Cambridge: Harvard University Press, 2007.

Traina, Cristina. Children and Moral Agency. Journal of the Society of Christian Ethics, v. 29, n. 2, p. 19-37, Fall / Winter 2009

Varga, Somogy. Authenticity as an Ethical Ideal. New York: Routledge, 2011.

Varga, Somogy. Core identifications: the motives that really "speak for us". Am Philos Q, v. 42, n. 4, p. 301-317, Oct. 2015.

Varga, Somogy; Guignon, Charles. Authenticity. Stanford Encyclopedia of Philosophy, Feb. 2020. Available at <https://plato.stanford.edu/entries/authenticity>. Accessed on: August 30th, 2020.

received in: 01.11.2020

approved in: 13.06 .2021 